We wish to thank Dr. T. J. Thomson, University Department of Materia Medica, Stobhill General Hospital, for his permission to study patients under his care. Mr. P. S. Waldie and the staff of the department of audio visual services at Stobhill General Hospital prepared the tables and illustrations.

\section{References}

Benoit, F. L., Martin, R. L., and Watten, R. H. (1965). Annals of Internal Medicine, 63, 604

Bloom, W. L. (1959). Metabolism, 8, 214 .

Cahill, G. F., et al. (1966). fournal of Clinical Investigation, 45, 1751.
Cohn, S. H., and Dombrowski, C. S. (1970). Fournal of Nuclear Medicine, $11,239$.

Drenick, E. J., Swendsied, M. E., Blahd, W. H., and Tuttle, S. G. (1964). fournal of the American Medical Association, 187, 100.

Duncan, G. G., Jenson, W. K., Frazer, R. I., and Cristofari, F. C. (1962). Fournal of the American Medical Association, 181, 309.

Felig, P., Owen, O. E., Wahren, J., and Cahill, G. F. (1969). Fournal of Clinical Investigation, 48, 584.

Goldblatt, P. B., Moore, M. E., and Stunkard, A. J. (1965). Fournal of the American Medical Association, 192, 1039.

Graham, J. A. (1970). Lancet, 1, 386.

Kinney, J. M., Duke, J. H., Long, C. L., and Gump, F. E., (1970). Fourna of Clinical Pathology, 23, Suppl. No. 4, p. 65.

Page, M. A., and Williamson, D. H. (1971). Lancet, 2, 66.

Rapoport, A., From, G. L. A., and Husdan, H. (1965). Metabolism, 14, 31

Runcie, J., and Thomson, T. J. (1970). British Medical fournal, 3, 432

Thomson, T. J., Runcie, J., and Miller, V. (1966). Lancet, 2, 992.

\title{
Long-term Follow-up of Therapeutic Starvation
}

\author{
J. A. INNES, \\ I. W. CAMPBELL, \\ C. J. CAMPBELL, \\ A. L. NEEDLE, J. F. MUNRO
}

British Medical Fournal, 1974, 2, 356-359

\section{Summary}

A total of 75 grossly obese patients were admitted to hospital for 80 episodes of prolonged starvation. Five took their own discharge within two weeks of admission and 12 defaulted from follow-up within 12 months of discharge. The others were all followed up for periods of 12 to 64 months. Altogether 39 episodes in 34 patients were classified as failures, eight as modified successes, and 16 as successes, though five of the latter patients subsequently defaulted. Success was associated with regular follow-up attendance but could not be otherwise predicted. A number of patients obtained tangible benefit from starvation despite a subsequent gain in weight.

\section{Introduction}

Starvation is an effective method of weight reduction but entails lengthy periods of stay in hospital and is not withour risk. It can be justified only if there is a pressing need for temporary weight loss or if the long-term results are superior to those obtained with conventional treatment. Previous experience had suggested that prolonged inpatient starvation might be of permanent value if patients were reduced to within $25 \%$ in excess of their ideal weight (Munro et al., 1970). We describe here the further follow-up of 75 patients with refractory obesity after fasting.

\section{Patients and Methods}

All the patients had failed to make satisfactory progress while attending an obesity clinic, had expressed the desire to be

\section{Eastern General Hospital, Edinburgh}

J. A. INNES, M.B., M.R.C.P., Registrar

W. CAMPBELL, M.B., M.R.C.P., Senior House Officer (Now Registrar in General Medicine, Royal Infirmary, Edinburgh)

J. F. MUNRO, M.B., F.R.C.P., Consultant Physician

Edenhall Hospital, Musselburgh, Midlothian

C. J. CAMPBELL, M.B., M.R.C.P., Senior House Officer (Now Registrar, Diabetic Department, Royal Infirmary, Edinburgh) A. L. NEEDLE, M.B., B.S., Senior House Officer (Present address: Western admitted to hospital for starvation, and were willing to remain in hospital until reduced to within $25 \%$ in excess of their ideal weight. Altogether 27 were male patients with an average age of 30 years (range 14 to 53 years) and 48 were female patients with an average of 29 years (range 15 to 57 years). They were admitted to a hospital with good rehabilitative facilities and began the starvation regimen after a short assessment period. The emphasis throughout was on trust rather than supervision and many admitted to periodic cheating. Initially a low-energy, carbohydrate-restricted meal was provided if specifically requested and many took one such meal a week. This offer was subsequently withheld but in other respects the regimen as previously described was followed (Munro et al., 1970).

Five patients (three women and two men) discharged themselves within a week or so and are excluded from further analysis. The mean admission weight of the remaining 45 women was $75.3 \%$ (range 41 to $141 \%$ ) in excess of their ideal weight and that of the 25 men $77.5 \%$ (range 45 to $123 \%$ ) in excess of their ideal weight.

At the completion of fasting patients were re-fed in hospital for four to seven days and offered further dietary advice. During follow-up the policy was to see them at intervals of four weeks or less. They were given every encouragement to lose weight and they and their close relatives had the opportunity of attending a monthly "group" session held during and after starvation. Many were treated with anorectic drugs, four wene readmitted for starvation, and 11 underwent funther shont periods of outpatient fasting. The patients were subdivided according to sex, percentage in excess of their ideal weight at the time of admission, and whether or not they reduced to within $25 \%$ in excess of their ideal weight at the completion of fasting. The following criteria were applied to evaluate the outcome of treatment: default, default from the clinic within 12 months of discharge and without subsequent reattendance; failure, a gain of $15 \mathrm{~kg}$ or of $50 \%$ of the total weight lost during starvation; modified success, a gain of 10 to $15 \mathrm{~kg}$ or of 33 to $50 \%$ of the total weight lost during starvation; success, a gain of less than $10 \mathrm{~kg}$ and less than $33 \%$ of the weight lost. Patients followed for at least 12 months but who then failed to attend were classified as "successes," "modified successes," or "failures," with subsequent default.

Results

During a mean fast of 14 weeks the mean weight loss was $29.6 \mathrm{~kg}$, but only 39 patients, including four of the 12 most 
obese, reduced to within $25 \%$ in excess of their ideal weight. The mean weight changes in the various subgroups and the follow-up results ane shown in tables I and II. After discharge 12 patients defaulted within a year; one died in a road traffic accident and eight were known to have left the district. A further six defaulted after at least 12 months of follow-up and 24 other patients were lost at some stage of follow-up but subsequently reattended. The mean period of follow-up was 28.2 months (range 12 to 64 months), during which the mean weight in excess of the ideal increased from $28.2 \%$ (range 7 to $83 \%$ ) to $62.7 \%$ (range nil to $137 \%$ ). At the time of writing 24 patients were in excess of their preadmission weight.

A total of 39 episodes in 34 patients resulted in failure; 19 occurred after reduction to within $25 \%$ in excess of the ideal weight (figs. 1 and 2). Irrespective of whether this was achieved or not, some patients regained weight exceptionally rapidly (table III, cases 1 and 2). Others managed to maintain their discharge weight for long periods only then to relapse. This was often associated with default but sometimes occurred for other reasons. For example, a mainline engine driver had attended regularly for 36 months without an appreciable gain in weight. He was then seen by a dootor unfamiliar with his problem and discharged from the clinic. Though the error was immediately detected and corrected he began to eat compulsively, in order, he said, to demonstrate to the doctors the importance of his regular attendance (table III, case 4). Eight episodes were classified as "modified successes" and included five patients who reduced to within $25 \%$ in excess of their ideal weight (figs. 3 and 4; table III, case 5). Of the 16 successes five were subsequently lost to

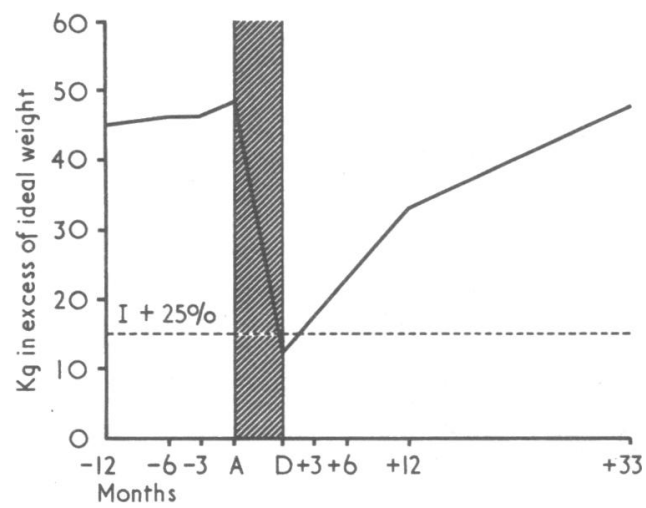

FIG. 1-Mean weight change of follow-up failures who reduced to within $25 \%$ in excess of their ideal weight (19 episodes). I = Ideal. A = Admission. $D=$ Discharge.

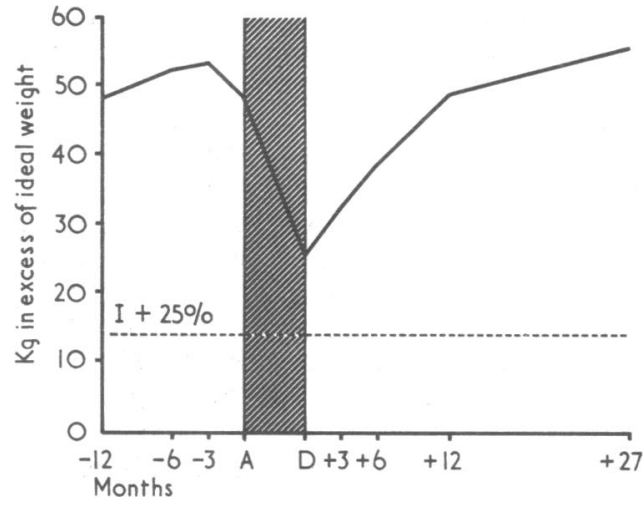

FIG. 2-Mean weight change of follow-up failures who failed to reduce to within $25 \%$ in excess of their idea weight (20 episodes). $I=$ Ideal. $A=A d m i s s i o n . ~ D=$ Discharge. TABLE I-Outcome of 47 Episodes of Starvation in Female Patients related to $\%$ in Excess of Ideal Weight on Admission and Ability to Reduce to within $25 \%$ in
Excess of Ideal Weight

\begin{tabular}{|c|c|c|c|c|c|c|}
\hline & $\%$ Excess on Admission: & $40-59$ & $60-79$ & $80-99$ & $\geqslant 100$ & Total \\
\hline & No of Episode: & 12 & 21 & 7 & 7 & 47 \\
\hline & Weight loss in kg (range): & $\begin{array}{c}14 \cdot 7 \\
(2 \cdot 0-27 \cdot 0)\end{array}$ & $\begin{array}{c}24 \cdot 8 \\
(14 \cdot 0-36 \cdot 0) \\
\end{array}$ & $\begin{array}{c}36 \cdot 8 \\
(28 \cdot 0-43 \cdot 0)\end{array}$ & $\begin{array}{c}47 \cdot 7 \\
(27 \cdot 0-72 \cdot 0) \\
\end{array}$ & $\begin{array}{c}27 \cdot 4 \\
(2 \cdot 0-72 \cdot 0)\end{array}$ \\
\hline $\begin{array}{l}\text { Reduced to }<25 \% \text { in Excess of } \\
\text { of Ideal Weight } \\
\text { Reduced to }>25 \% \text { in Excess of } \\
\text { Ideal Weight }\end{array}$ & $\begin{array}{l}\text { No. } \\
\text { Default } \\
\text { Success } \\
\text { Modified success } \\
\text { Failure } \\
\text { No. } \\
\text { Default } \\
\text { Success } \\
\text { Modified success } \\
\text { Failure }\end{array}$ & $\begin{array}{c}8 \\
1 \\
2+1 * \\
1 \\
3 \\
4 \\
1 \\
0 \\
0 \\
3\end{array}$ & $\begin{array}{c}10 \\
2 \\
1+1 \dagger \\
1+1 \ddagger \\
4 \\
11 \\
2 \\
3 \\
2 \\
4\end{array}$ & $\begin{array}{c}3 \\
1 \\
0 \\
0 \\
2 \\
4 \\
0 \\
0+1 \dagger \\
0 \\
3\end{array}$ & $\begin{array}{l}1 \\
0 \\
0 \\
0 \\
1 \\
6 \\
1 \\
0 \\
1 \\
4\end{array}$ & $\begin{array}{c}22 \\
4 \\
3+1 *+1 \dagger \\
2+1 \ddagger \\
10 \\
25 \\
4 \\
3+1 \dagger \\
3 \\
14\end{array}$ \\
\hline
\end{tabular}

Defaulted at 24 months.

Defaulted at 18 months.

TABLE II-Outcome of 28 Episodes of Starvation in Male Patients related to \% in Excess of Ideal Weight on Admission and Ability to Reduce to within $25 \%$ in Ideal Weight

\begin{tabular}{|c|c|c|c|c|c|c|}
\hline & $\%$ Excess on admission: & $40-59$ & $60-79$ & $80-99$ & $>100$ & Total \\
\hline & No. of episodes: & 6 & 13 & 4 & 5 & 28 \\
\hline & Weight loss in kg (range): & $\begin{array}{c}24 \cdot 8 \\
(16 \cdot 0-39 \cdot 0)\end{array}$ & $\begin{array}{c}27 \cdot 6 \\
(13 \cdot 0-46 \cdot 0)\end{array}$ & $\begin{array}{c}37 \cdot 0 \\
(21 \cdot 0-46 \cdot 0)\end{array}$ & $\begin{array}{c}57 \cdot 6 \\
(38 \cdot 0-77 \cdot 0) \\
\end{array}$ & $\begin{array}{c}33 \cdot 1 \\
(13 \cdot 0-77 \cdot 0)\end{array}$ \\
\hline $\begin{array}{l}\text { Reduced to }<25 \% \text { in Excess of } \\
\text { Ideal Weight } \\
\text { Reduced to }>25 \% \text { in Excess of } \\
\text { Ideal Weight }\end{array}$ & $\begin{array}{l}\text { No. } \\
\text { Default } \\
\text { Success } \\
\text { Modified success } \\
\text { Failure } \\
\text { No. } \\
\text { Default } \\
\text { Success } \\
\text { Modified success } \\
\text { Failure }\end{array}$ & $\begin{array}{l}6 \\
1 \\
1 \\
0 \\
4 \\
0 \\
0 \\
0 \\
0 \\
0\end{array}$ & $\begin{array}{c}7 \\
1 \\
1+1 * \\
2 \\
2 \\
6 \\
0 \\
2 \\
0 \\
4\end{array}$ & $\begin{array}{l}1 \\
0 \\
0 \\
0 \\
1 \\
3 \\
1 \\
1 \\
0 \\
1\end{array}$ & $\begin{array}{c}3 \\
0 \\
0+1 \dagger \\
0 \\
2 \\
2 \\
1 \\
0 \\
0 \\
1\end{array}$ & $\begin{array}{c}17 \\
2 \\
2+1 *+1 \dagger \\
2 \\
9 \\
11 \\
2 \\
3 \\
0 \\
6\end{array}$ \\
\hline
\end{tabular}


TABLE III-Clinical Data on Nine Patients

\begin{tabular}{|c|c|c|c|c|c|c|c|c|c|c|c|c|c|c|c|c|c|}
\hline \multirow{2}{*}{$\begin{array}{l}\text { Case } \\
\text { No. }\end{array}$} & \multirow{2}{*}{\multicolumn{2}{|c|}{ Age and Sex }} & \multirow{2}{*}{$\begin{array}{c}\text { Ideal } \\
\text { Weight } \\
(\mathbf{k g})\end{array}$} & \multicolumn{2}{|c|}{$\begin{array}{l}\text { Excess Weight } \\
\text { Before Fast (kg) }\end{array}$} & \multicolumn{2}{|c|}{$\begin{array}{c}\text { Excess Weight } \\
\text { at Fast }\end{array}$} & \multirow{2}{*}{$\begin{array}{c}\text { Dura- } \\
\text { tion of } \\
\text { Fast } \\
\text { (Weeks) }\end{array}$} & \multicolumn{2}{|c|}{$\begin{array}{l}\text { Excess Weight } \\
\text { on Discharge }\end{array}$} & \multicolumn{4}{|c|}{$\begin{array}{l}\text { Excess Weight after } \\
\text { Discharge (kg) }\end{array}$} & \multicolumn{2}{|c|}{$\begin{array}{c}\text { Final Excess } \\
\text { Weight }\end{array}$} & \multirow{2}{*}{$\begin{array}{c}\text { Length } \\
\text { of } \\
\text { Follow- } \\
\text { up } \\
\text { (Months) }\end{array}$} \\
\hline & & & & $\begin{array}{c}12 \\
\text { Months }\end{array}$ & $\stackrel{3}{\text { Months }}$ & kg & $\begin{array}{l}\text { of Ideal } \\
\text { Woight } \\
\text { Weigh }\end{array}$ & & kg & $\begin{array}{c}\% \text { Ideal } \\
\text { Weight }\end{array}$ & Months & $\begin{array}{c}12 \\
\text { Months }\end{array}$ & $\begin{array}{c}24 \\
\text { Months }\end{array}$ & $\begin{array}{l}36 \\
\text { Months }\end{array}$ & kg & $\begin{array}{l}\% \text { Ideal } \\
\text { Weight }\end{array}$ & \\
\hline $\begin{array}{l}1 \\
2 \\
3 \\
4 \\
5 \\
6 \\
7 \\
8\{ \\
9 \\
9\end{array}$ & $\begin{array}{l}34 \\
33 \\
26 \\
42 \\
41 \\
18 \\
41 \\
29 \\
31 \\
46 \\
49\end{array}$ & $\begin{array}{l}\text { M. } \\
\text { M. } \\
\text { F. } \\
\text { M. } \\
\text { F. } \\
\text { M. } \\
\text { M. } \\
\text { M. }\end{array}$ & $\begin{array}{l}78 \\
76 \\
59 \\
73 \\
61 \\
71 \\
68 \\
70 \\
66\end{array}$ & $\begin{array}{r}74 \\
99 \\
39 \\
28 \\
29 \\
51 \\
45 \\
* \\
97\end{array}$ & $\begin{array}{r}81 \\
76 \\
37 \\
31 \\
36 \\
62 \\
43 \\
* \\
98\end{array}$ & $\begin{array}{l}90 \\
81 \\
43 \\
32 \\
43 \\
69 \\
34 \\
85 \\
62 \\
96 \\
81\end{array}$ & $\begin{array}{r}115 \\
107 \\
73 \\
44 \\
71 \\
97 \\
50 \\
121 \\
89 \\
145 \\
123\end{array}$ & $\begin{array}{l}19 \\
27 \\
10 \\
13 \\
29 \\
19 \\
13 \\
10 \\
19 \\
15 \\
45\end{array}$ & $\begin{array}{r}45 \\
18 \\
12 \\
3 \\
9 \\
26 \\
8 \\
9 \\
17 \\
56 \\
23\end{array}$ & $\begin{array}{r}58 \\
24 \\
20 \\
4 \\
15 \\
37 \\
11 \\
13 \\
24 \\
85 \\
35\end{array}$ & $\begin{array}{r}80 \\
47 \\
12 \\
4 \\
15 \\
17 \\
12 \\
40 \\
75 \\
25\end{array}$ & $\begin{array}{r}107 \\
56 \\
2 \\
3 \\
15 \\
21 \\
12 \\
64 \\
75 \\
68 \\
33\end{array}$ & $\begin{array}{r}8 \\
14 \\
19 \\
60 \\
12 \\
\\
80\end{array}$ & $\begin{array}{r}15 \\
6 \\
25\end{array}$ & $\begin{array}{r}104 \\
56 \\
48 \\
43 \\
21 \\
23 \\
15 \\
62 \\
75 \\
81 \\
38\end{array}$ & $\begin{array}{r}133 \\
74 \\
81 \\
59 \\
34 \\
32 \\
22 \\
89 \\
107 \\
123 \\
58\end{array}$ & $\begin{array}{l}14 \\
12 \\
52 \\
60 \\
30 \\
60 \\
26 \\
18 \\
12 \\
27 \\
19\end{array}$ \\
\hline
\end{tabular}

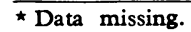

follow-up, and at the time of writing their status was uncertain. Of the 11 still attending five reduced to within $25 \%$ in excess of their ideal weight. The mean weight changes of this group and of the six who failed to reduce to within $25 \%$ in excess of their ideal weight are shown in figs. 5 and 6 . The latter group included a patient whose weight increased to almost the preadmission value but who by means of shont spells of outpatient starvation reduced it to less than his weight at discharge (table III, case 6). Most of the "successes," however, maintained a fairly constant weight (table III, case 7).

Of the four patients readmitted two were reduced on both occasions to within $25 \%$ in excess of their ideal weight only to regain weight rapidly (table III, case 8). The third continued to struggle to keep her weight at about $100 \mathrm{~kg}$ compared with her prestarvation weight of $162 \mathrm{~kg}$ and was a "modified success" (table III, case 9). The fourth regained weight rapidly after the second admission but did much better after a third period of starvation and was also a "modified success."

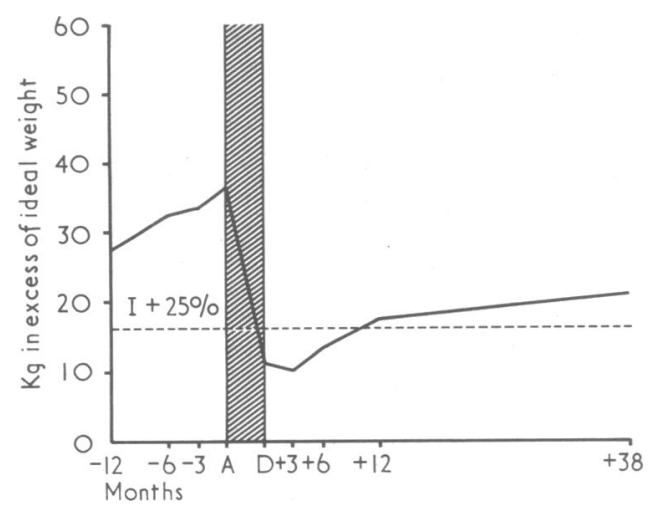

FIG. 3-Mean weight change of follow-up modified successes who reduced to within $25 \%$ in excess of their

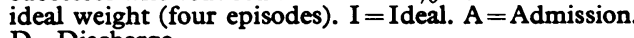
$\mathrm{D}=$ Discharge.

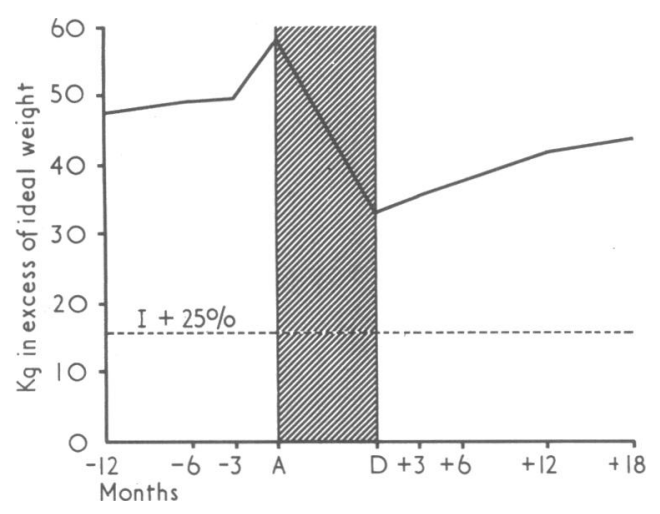

FIG. 4-Mean weight change of follow-up modified successes who failed to reduce to within $25 \%$ in excess of their ideal weight (three episodes). I=Ideal. $A=$ Admission. $\mathrm{D}=\mathrm{Discharge}$.

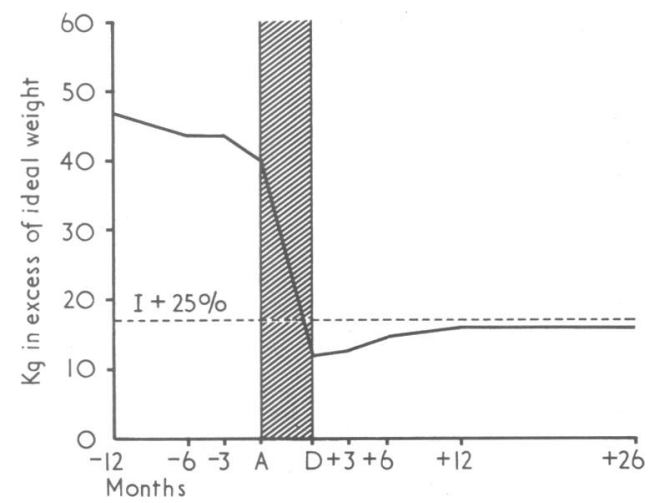

FIG. 5-Mean weight change of follow-up successes who reduced to within $25 \%$ in excess of their ideal weight (five episodes). I=Ideal. $\mathrm{A}=$ Admission. $\mathrm{D}=$ Discharge

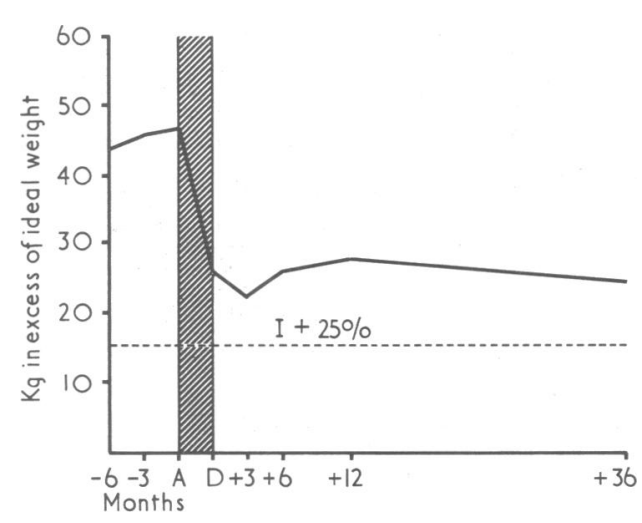

FIG. 6-Mean weight change of follow-up successes who failed to reduce to within $25 \%$ in excess of their ideal weight (six episodes). I $=$ Ideal. $\mathbf{A}=$ Admission $\mathrm{D}=$ Discharge.

\section{Discussion}

Analysis of reports of follow-up results suggests that therapeutic starvation for four weeks or less does not produce lasting weight loss superior to that obtained with conventional treatment either in patients with refractory obesity (MacCuish et al., 1968) or at time of initial referral to hospital (Bloom, 1959; Harrison and Harden, 1966; Gilliland, 1968; Hermann and Iversen, 1968; Maagoe and Mogensen, 1970). After prolonged fasting a massive regain of weight is common (Kollar et al., 1968; Swanson and Dinello, 1970) but a proportion of patients do not regain weight during a followup of 2 to 24 months (Karns, 1966; Munro et al., 1970; Rooth and Carlstrom, 1970).

The overall results of follow-up for 12 months or more were clearly disappointing in that two-thirds of the patients 
were "failures" and more than one-third actually regained all the weight lost. Moreover, though most of the "successes" or "modified successes" continued to maintain a steady weight the incidence of failure increased with the length of followup. This was especially true during the first 12 months, and follow-up reports for such short periods are of limited value. The results for the male and female patients appeared to be similar and suggest that those most overweight are least likely to succeed; however, the initial percentage excess weight was of no clear predictive value. We failed to substantiate the previous impression that the ability to reduce to within $25 \%$ in excess of the ideal weight is associated with increased prospeots of long-term success. Long-term success, however, is closely correlated with regular attendance at the follow-up clinic, and only two patients were known to have kept their weight down despite a lengthy lapse of follow-up. Some of the patients who regained weight rapidly admitted that though superficially their eating habits had been reformed they continued to eat excessively but in secret.

All the patients were "failures" before admission and the primary reason for selection was their inability to respond satisfactorily to conventional treatment despite regular supervision at an obesity clinic for at least a year. All were suffering either physically or psychologically from their morbid obesity. Thus for the small proportion of successes a mean weight loss of $27 \mathrm{~kg}$ at a mean follow-up of 27 months represents a wonthwhile achievement. Success, however, cannot be gauged solely in terms of weight reduction. Ten patients had 12 elective operations, including hiatus hernia repair, cholecystectomy, and total hip replacement. Nine married, and among the women there were six pregnancies, including one full-term delivery in a previous habitual abonter. Eleven patients held jobs which previously they could not have obtained. It follows that the distinction between success and failure is necessarily arbitrary, and many who regained weight did not regret the time spent in hospital.

Therapeutic starvation could be better justified if patient selection were improved, but at present the long-term sequelae of the other form of radical therapy, bypass surgery, are uncentain. The current policy is to offer surgery only to selected patients who have regained weight after starvation.

We wish to thank the many doctors, the nursing staff, and the other staff who were concerned in the care of these patients, and are grateful to Servier Laboratories for their very generous financial support.

\section{References}

Bloom, W. L. (1959). Metabolism, 8, 214.

Gilliland, I. C. (1968). Postgraduate Medical fournal, 44, 58.

Harrison, M. T., and Harden, R. M. (1966). Lancet, $2,1340$.

Harrison, M. T., and Harden, R. M. (1966). Lancet, 2, 13.

Hermann, L. (1966). Fournal of the American Medical Association, 197, 22

Kollar, E. J., Atkinson, R. M., and Albin, D. L. (1968). Psychosomatics, 10, 125.

Maague, H., and Mogensen, E. F. (1970). Danish Medical Bulletin, 17, 206.

MacCuish, A. C., Munro, J. F., and Duncan, L. J. P. (1968). British Medical Fournal, 1,91 .

Munro, J. F., MacCuish, A. C., Goodall, J. A. D., Fraser, J., and Duncan, L. J. P. (1970). British Medical fournal, 4, 712.

Rooth, G., and Carlström, S. (1970). Acta Medica Scandinavica, 187, 455 Swanson, D. W., and Dinello, K. (1970). Psychosomatic Medicine, 32, 209.

\title{
Secondary Respiratory Infection in Hospital Patients: Effect of Antimicrobial Agents and Environment
}

\author{
J. R. PHILP, R. C. SPENCER
}

British Medical fournal, 1974, 2, 359-362

\section{Summary}

A prospective study of 358 medical and 234 postoperative patients with clinical evidence of secondary chest infection showed that previous administration of antimicrobial agents greatly reduced the chance of obtaining a clear-cut laboratory report. In patients with radiographical evidence of pneumonia this led to a fourfold decrease in the overall rate of isolation of potential pathogens. Furthermore, 81 diverse "coliforms" were isolated from 258 medical and surgical patients who had received previous antimicrobial therapy while only four coliforms (all Escherichia coli) were isolated from 334 untreated patients. Thus the general hospital environment on its own seemed to have a negligible influence

\footnotetext{
Department of Bacteriology, Wright-Fleming Institute, St. Mary's Hospital, London W.2

J. R. PHILP, M.D., M.R.C.P., Associate Professor of Medicine (Present address: Department of Medicine, Bowman Gray School of Medicine, Winston-Salem, North Carolina 27103)

R. C. SPENCER, M.B., B.S., Senior Registrar
}

in promoting the growth of coliform flora in sputum. Any unique effect of underlying disease in this regard was masked by that of previous therapy. Finally, the results raised the possibility that previous antimicrobial therapy might have increased the risk of secondary pneumonia in hospital patients.

\section{Introduction}

In the six months before this study a pilot study showed that potential bacterial pathogens were isolated from less than a third of 1,560 sputa investigated in this laboratory. Of these isolates $56 \%$ were Gram-negative "coliform" bacilli whose significance was often difficult to assess. Consequently this study was carried out in an attempt to correlate bacterological findings in sputum with radiographical appearances, underlying disease (Stratford et. al., 1968; Johansen et. al., 1969), residence in the hospital environment (Johansen et al., 1972), and previous administration of antimicrobial agents (Lipman et al., 1946; Ory et al., 1946; Long, 1947; Meads et al., 1951; McCurdy and Neter, 1952; Elmes et al., 1953; Petersdorf et al., 1957; Louria and Kaminski, 1962; Tillotson and Finland, 1969; Price and Sleigh, 1970). It was hoped to define more clearly the clinical significance of various potential pathogens with a view to more rational therapy in individual patients. 